\title{
A AÇÃO RESCISÓRIA, O ART. 525, § 15 DO NOVO CÓdIGO DE PROCESSO CIVIL E O CONTROLE DE CONSTITUCIONALIDADE
}

José Luiz Ragazzi ${ }^{1}$

Cláudio Augusto Saad Abujamra ${ }^{2}$

\section{RESUMO}

O presente trabalho tem por objetivo demonstrar a incompatibilidade da utilização da ação rescisória, baseada no $\S 15$ do art. 525 do Código de Processo Civil, para reaviventar questões já decididas com trânsito em julgado, uma vez que a tanto o controle de constitucionalidade não deve se prestar. Como método, analisar-se-á, inicialmente, aspectos da coisa julgada, da ação rescisória e do controle de constitucionalidade, para então aplicar-se tais aspectos para tomada de posição em relação ao objetivo proposto.

Palavras-chave: Ação rescisória; código de processo civil; controle de constitucionalidade.

\footnotetext{
${ }^{1}$ Doutor pela PUCSP, Mestre pela ITE-Bauru, Professor do PPGD da ITE-Bauru, Sistema Constitucional de Garantia de Direitos e Advogado.

2 Mestrando no PPGD Sistema Constitucional de Garantia de Direitos da ITE-Bauru, Sistema Constitucional de Garantia de Direitos
} 
I - Introdução, objetivo e método

O presente trabalho tem por objetivo demonstrar a incompatibilidade da utilização da ação rescisória, baseada no $§ 15$ do art. 525 do Código de Processo Civil, para reaviventar questões já decididas com trânsito em julgado, uma vez que a tanto o controle de constitucionalidade não deve se prestar.

Como método, analisar-se-á, inicialmente, aspectos da coisa julgada, da ação rescisória e do controle de constitucionalidade, para então aplicar-se tais aspectos para tomada de posição em relação ao objetivo proposto.

\section{II - COISA JULGADA: ASPECTOS RELEVANTES:}

De proêmio, julga-se importante, ao tratar do tema da coisa julgada, mencionar a doutrina de Vicente Ráo em relação à problemática da irretroatividade de lei e a ratio do ensinamento, que se funda na lição de Portalis, que não pode passar despercebida, razão pela qual se o transcreve:

“... a inviolabilidade do passado é princípio que encontra fundamento na própria natureza do ser humano, pois, segundo as sábias palavras de Portalis: 'o homem, que não ocupa senão um ponto no tempo e no espaço, seria o mais infeliz dos seres, se não se pudesse julgar seguro nem sequer quanto à sua vida passada. Por essa parte de sua existência, já não carregou todo o peso de seu destino ? O passado pode deixar dissabores, mas põe termo a todas as incertezas. Na ordem da natureza, só o futuro é incerto e esta própria incerteza é suavizada pela esperança, a fiel companheira de nossa fraqueza. Seria agravar a triste condição da humanidade, querer mudar, através do sistema da legislação, o sistema da natureza, procurando, para o tempo que já se foi, fazer reviver as nossas dores, sem nos restituir nossas esperanças'.” (RÁO, 1997, volume 1, p. 359 )

Entende-se, pois, a partir disso, a relevância de tributar respeito à coisa julgada, instituto com dignidade constitucional. 
Segundo o art. $5^{\circ}$, inciso XXXV, da Constituição Federal, “a lei não prejudicará o direito adquirido, o ato jurídico perfeito e a coisa julgada;" e a partir do mandamento da $\mathrm{CF}$, se pode depreender que a função da coisa julgada "é a de proporcionar segurança nas relações jurídicas, sabendo-se que a insegurança é gravíssimo fator perverso que prejudica os negócios, o crédito, as relações familiares e, por isso, a felicidade pessoal das pessoas ou grupos" (DINAMARCO, 2005, volume III, p. 294).

O conceito de desdobra para a classificação clássica entre a dimensão formal e a material, sendo que a primeira consiste na imutabilidade da sentença ou acórdão do Tribunal como ato jurídico processual e trata-se do "impedimento de qualquer recurso ou expediente processual destinado a impugná-la, de modo que, naquele processo, nenhum outro julgamento ser fará” (DINANARMCO, 2005, volume III, p. 295).

De outra compreensão a coisa julgada material, sobre a qual se afirma que "é a imutabilidade dos efeitos substanciais da sentença de mérito, transcende a vida do processo e atinge as pessoas", consistindo "na rigorosa intangibilidade das situações jurídicas criadas ou declaradas, de modo que nada poderá ser feito por elas próprias, nem por outro juiz, nem pelo próprio legislador, conforme Liebman, em Cândido Dinamarco (apud DINAMARCO, 2005, volume III, p. 299/300).

Em valor intangível no Estado Democrático, ambos os conceitos estão intimamente ligados à ideia de coisa julgada tem escopo de pacificação social do processo, centrado na eliminação de conflitos.

Quanto aos escopos, DINAMARCO na mesma obra afirma que se tem por necessária a distinção entre o escopo jurídico e o escopo social do processo, eis que o primeiro se relaciona à busca da verdade na fase de conhecimento, através do contraditório, da instrução e dos recursos, favorecendo o "fator de fidelidade à vontade concreta da lei”. Já o segundo refere-se à busca por acelerar o serviço jurisdicional e "torna-lo aderente à realidade do conflito e do seu modo de ser", visando "eliminar logo e de modo adequado o estado anti-social de insatisfação que deu causa ao processo" (DINAMARCO, 1999, p. 236).

Tal justifica a necessidade de conciliar duas exigências, em geral contrastantes da Justiça, a saber, "a da celeridade e a da ponderação", incumbindo "à boa técnica processual o estabelecimento do desejado racional e justo equilíbrio entre as duas exigências opostas, para que não se comprometa a qualidade do resultado da jurisdição 
por falta de conhecimento suficiente, nem se neutralize a eficácia social dos resultados bem concebidos, por inoportunidade decorrente da demora" (DINAMARCO, 1999, p. 231/232).

Especificamente sobre o escopo social do processo, o doutrinador ensina que "o importante não é o consenso em torno das decisões estatais, mas a imunização delas contra os ataques dos contrariados; e indispensável, para cumprimento da função pacificadora exercida pelo Estado legislando ou sub specie jurisdictionis, é a eliminação do conflito como tal, por meios que sejam reconhecidamente idôneos". (DINAMARCO, 1999,, p. 161).

\section{E prossegue:}

“... existe a predisposição a aceitar decisões desfavoráveis na medida em que cada um, tendo oportunidade de participar na preparação da decisão e influir no seu teor mediante observância do procedimento adequado (princípio do contraditório, legitimação pelo procedimento), confia na idoneidade do sistema em si mesmo. E, por fim: psicologicamente, às vezes, a privação consumada é menos incômoda que o conflito pendente: eliminado este desaparecem as angústias inerentes ao estado de insatisfação e esta, se perdurar, estará desativada de boa parte de sua potencialidade anti-social (DINAMARCO, 1999, P. 161).

Faz, no entanto, uma ressalva:

Isso não significa que a missão social pacificadora se dê por cumprida mediante o alcance de decisões, quaisquer que sejam e desconsiderado o teor das decisões tomadas. Entra aqui a relevância do valor justiça. Eliminar conflitos mediante critérios justos - eis o mais elevado escopo social das atividades jurídicas do Estado. (DINAMARCO, 1999, p. 161).

E arremata:

Também a autoridade da coisa julgada guarda relação com o escopo social do processo, uma vez que a definitiva pacificação não se obtém enquanto não conseguida a 'imunização' das decisões judiciais. Sabese até que a litispendência é extremamente aflitiva e sucede que as pessoas se tomam de inusitada a obsessiva angústia pela espera do 
resultado final do processo, após instaurado. $\mathrm{O}$ advento da definitividade aplaca as incertezas e elimina o estado anti-social de insatisfação. Não se desconsidera que essa autoridade de res judicata, 'imunizando' a decisão de mérito, mantém relação funcional com mais de um escopo do processo, ou seja, não somente com o de pacificação mas ainda (pelo menos) com o jurídico de atuação da vontade concreta da lei. Mas lá é que ela se sente com mais peso e relevância. Além disso, quando se pensa nas chamadas 'sentenças injustas', que são aquelas que por algum motivo conduzem a resultados não indicados no ordenamento jurídico substancial, tem-se a eliminação definitiva do conflito, com total 'imunização' do decidido contra novas investidas, apesar de em nada terem contribuído para a atuação da lei” (DINAMARCO, 1999, p. 167).

Verifica-se, enfim, que a coisa julgada é instrumento indispensável à segurança jurídica, valor caro ao Estado de Direito, tendo, inclusive, entre nós, estatura constitucional.

Da mesma forma, por tornar imutáveis os efeitos da decisão judicial, a coisa julgada corrobora para a eliminação do conflito e, consequentemente, para que se atinja o escopo social do processo.

\section{III- AÇÃO RESCISÓRIA: ASPECTOS RELEVANTES.}

Interessa, também, para atingirmos o objetivo deste trabalho, verificar alguns aspectos atinentes à ação rescisória, pois, em que pese a coisa julgada seja dogma constitucional, o ordenamento jurídico admite sua temperança, por meio da ação rescisória.

Conforme preleciona Nery Junior, o texto infraconstitucional que prevê a ação rescisória não é inconstitucional, "por força da aplicação do princípio constitucional da proporcionalidade, que flexibiliza a coisa julgada em função da gravidade dos vícios arrolados nos incisos do CPC 966.” (NERY JUNIOR, 2019, p. 2021).

Da mesma forma, Bastos e Martins ponderam que a própria Constituição se refere às ações rescisórias, ao cuidar das competências dos Tribunais. Daí a conclusão no sentido de que, "se a própria Constituição prevê a competência para o julgamento deste tipo de 
ação, é porque ela não a considera ofensiva da coisa julgada" (BASTOS e MARTINS, 1989, $2^{\circ}$ volume, p. 201).

Os mesmos autores concluem apontando que, "se é certo, portanto, que a coisa julgada é uma garantia importante a proteger as situações já consolidadas no passado, o certo é que ela tem de amoldar-se a imperativos outros, resultantes das circunstâncias em que há razões mais fortes a serem feitas valer do que a mera imutabilidade do já decidido" (BASTOS e MARTINS, 1989, $2^{\circ}$ volume, p. 201).

Há que se ponderar que, tradicionalmente, a legislação processual brasileira tem incluído no rol dos motivos que autorizam a ação rescisória a consideração de vícios ou situações que lhe são pré-existentes.

Confira-se o disposto no art. 798 do Código de Processo Civil de 1939:

“Art. 798. Será nula a sentença :

I - quando proferida :

a) para juiz peitado, impedido, ou incompetente racione material e;

b) com ofensa à coisa julgada;

c) contra literal disposição de lei.

I quando fundada em prova cuja falsidade se tenha apurado nø juízo criminal.

II - quando o seu principal fundamento for prova declarada falsa em Juízo criminal, ou de falsidade inequivocamente apurada na própria ação rescisória."

Da mesma forma, o Código de Processo Civil de 1.973:

“Art. 485. A sentença de mérito, transitada em julgado, pode ser rescindida quando:

I - se verificar que foi dada por prevaricação, concussão ou corrupção do juiz;

II - proferida por juiz impedido ou absolutamente incompetente;

III - resultar de dolo da parte vencedora em detrimento da parte vencida, ou de colusão entre as partes, a fim de fraudar a lei;

IV - ofender a coisa julgada;

V - violar literal disposição de lei;

V1 - se fundar em prova, cuja falsidade tenha sido apurada em processo criminal ou seja provada na própria ação rescisória; 
Vll - depois da sentença, o autor obtiver documento novo, cuja existência ignorava, ou de que não pôde fazer uso, capaz, por si só, de Ihe assegurar pronunciamento favorável;

VIII - houver fundamento para invalidar confissão, desistência ou transação, em que se baseou a sentença;

IX - fundada em erro de fato, resultante de atos ou de documentos da causa;"

Note-se que, mesmo ao se referir a documento novo, no inciso VII, a lei processual civil não estava a aludir ao “constituído posteriormente. $\mathrm{O}$ adjetivo 'novo' expressa o fato de só agora ser ele utilizado, não a ocasião em que veio a formar-se. Ao contrário: em princípio, para admitir-se a rescisória, é preciso que o documento já existisse ao tempo do processo em que se proferiu a sentença. Documento 'cuja existência' a parte ignorava é, obviamente, documento que existia; “documento que ela não pôde fazer uso" é, também, documento que, noutras circunstâncias, poderia ter sido utilizado, e portanto existia. Fosse qual fosse o motivo da impossibilidade de utilização, é necessário que haja sido estranho à vontade da parte. Esta deve ter-se visto impossibilitada, sem culpa sua, de usar o documento, ...” (BARBOSA MOREIRA, 1998, volume V, p. 135/136).

Por fim, o Código de Processo Civil de 2015 assim estatui:

“Art. 966. A decisão de mérito, transitada em julgado, pode ser rescindida quando:

I - se verificar que foi proferida por força de prevaricação, concussão ou corrupção do juiz;

II - for proferida por juiz impedido ou por juízo absolutamente incompetente;

III - resultar de dolo ou coação da parte vencedora em detrimento da parte vencida ou, ainda, de simulação ou colusão entre as partes, a fim de fraudar a lei;

IV - ofender a coisa julgada;

V - violar manifestamente norma jurídica;

VI - for fundada em prova cuja falsidade tenha sido apurada em processo criminal ou venha a ser demonstrada na própria ação rescisória;

VII - obtiver o autor, posteriormente ao trânsito em julgado, prova nova cuja existência ignorava ou de que não pôde fazer uso, capaz, por si só, de lhe assegurar pronunciamento favorável;

VIII - for fundada em erro de fato verificável do exame dos autos." 
Ressalte-se que a violação a literal disposição de lei

“...que propicia o manejo da ação rescisória, fundada no art. 485, V, do Código de Processo Civil, pressupõe que a norma legal tenha sido ofendida na sua literalidade pela decisão rescindenda, ou seja, é a decisão de tal modo teratológica que consubstancia o desprezo do sistema de normas pelo julgado rescindendo." (Superior Tribunal de Justiça, AR 2625/PR, rel. Ministro Sebastião Reis Junior, Terceira Seção, j. 11/09/2013).

E, por violação manifesta da norma jurídica entende-se a contida na decisão de mérito transitada em julgado que não aplicou a lei ou a aplicou incorretamente, "exigindose, agora, de forma expressa, que tal violação seja visível, evidente ....” (NERY JUNIOR, 2019, p. 2024).

Como se observa, mesmo a violação a literal disposição de lei ou a violação manifesta de norma jurídica refere-se a um vício de fundamentação da decisão rescindenda, levando em conta o ordenamento jurídico à época de sua prolação.

Prosseguindo, ainda em relação ao art. 966, inciso V, do Código de Processo Civil, não se pode perder de vista a sempre lembrada lição de Kelsen:

O Direito a aplicar forma, em todas estas hipóteses, uma moldura dentro da qual existem várias possibilidades de aplicação, pelo que é conforme ao Direito todo ato que se mantenha dentro deste quadro ou moldura, que preencha esta moldura em qualquer sentido possível. Se por 'interpretação' se entende a fixação da via cognoscitiva do sentido do objeto a interpretar, o resultado da interpretação jurídica somente pode ser a fixação da moldura que representa o Direito a interpretar e, consequentemente, o conhecimento das várias possibilidades que dentro desta moldura existem. Sendo assim, a interpretação de uma lei não deve necessariamente conduzir a uma única solução como sendo a única correta, mas possivelmente a várias soluções que - na medida em que apenas sejam aferidas pela lei a aplicar - têm igual valor, se bem que apenas uma delas se torne Direito positivo no ato do órgão aplicador do Direito - no ato do Tribunal, especialmente. Dizer que uma sentença está fundada na lei, não significa, na verdade, senão que ela está contida na moldura ou quadro que a lei representa - não significa que ela é a norma individual, mas apenas que é uma das normas individuais que podem ser produzidas dentro da moldura da norma geral. (KELSEN, 1987, p. 366). 
Nesta construção de raciocínio, um dos indicativos a revelar que não ocorre violação manifesta de norma jurídica se situa na verificação de que a interpretação está contida na "moldura da norma geral", de que fala Kelsen.

Importante é também destacar, de resto, que a ação rescisória fundada no inciso $\mathrm{V}$ do art. 485 do CPC/73 e, também, no inciso V do art. 966 do CPC/2015) não é instrumento orientado à uniformização de jurisprudência.

Nesse sentido, a lição de PEREIRA:

Este é um dos pontos de distinção entre a ação rescisória do recurso extraordinário. Embora sob a égide do Código anterior, houvesse entendimento de que a ação rescisória e o recurso extraordinário têm a mesma finalidade, qual seja, manter a unidade do direito federal, este institutos não se confundem. A ação rescisória, fundada na violação à literal disposição de lei, não visa a uniformização da interpretação das regras jurídicas. Tal função é inerente ao recurso extraordinário. Pontes de Miranda já afirmara que a ação rescisória não visa, como o recurso extraordinário, manter a unidade do direito federal. $O$ remédio da ação rescisória nunca possuiu tal função.

Cabe esclarecer que, quando a autora se refere, no texto supra, a "Código anterior", está fazendo alusão ao Código de Processo Civil de 1.939 e o mesmo ponto de vista é compartilhado por GONÇALVES, ao tratar da função nomofilática conferida aos Tribunais Superiores:

Essa função, sublinhe-se o ponto, é antiética à teleologia da rescisória, a qual não é instrumento destinado a impugnar disceptações de qualquer ordem, já que não tem por fim uniformizar o processo interpretativo, senão proteger o direito da parte. Significa dizer que, embora possa contribuir satelitariamente para a unidade da ordem jurídica, este não é seu objetivo primordial. (GONÇALVES, 2016, p. 173).

Em resumo, embora a coisa julgada seja garantia constitucional, admite-se, excepcionalmente, por força do princípio da proporcionalidade, sua rescisão em hipóteses específicas e taxativas.

Cabe ao legislador ponderar entre a segurança jurídica e outros valores igualmente dignos de proteção no ordenamento jurídico, para definir em quais situações é possível a ação rescisória ou a inviolabilidade da coisa julgada 
Destaque-se, também, que tradicionalmente, o legislador pátrio tem elencado como causas para ação rescisória vícios que lhe são pré-existentes, bem como que a ação em questão não tem função de uniformização de jurisprudência.

\section{IV- AÇÃO RESCISÓRIA, O DISPOSTO NO ART. 966, V, DO CÓDIGO DE PROCESSO CIVIL DE 2015 E OS PRECEDENTES JURISPRUDENCIAIS.}

A compreensão do tema não pode prescindir da análise do que está disposto no art. 966, inciso V, do novo Código de Processo Civil:

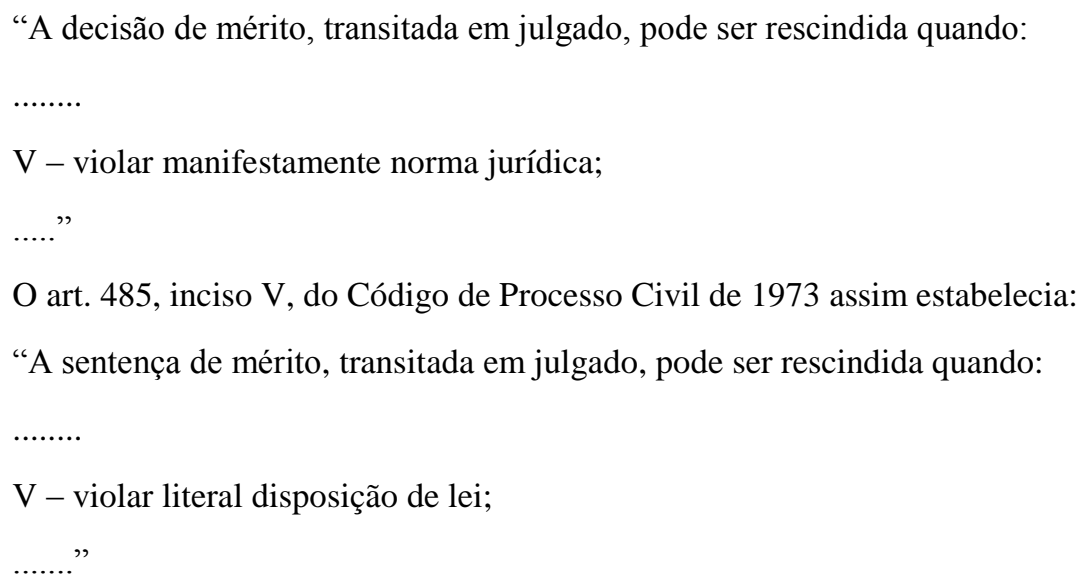

Este confronto semântico e técnico instiga ao registro da análise do entendimento do Supremo Tribunal Federal e do Superior Tribunal de Justiça, no tocante à aplicação destes dispositivos legais, quando se tem em vista ação rescisória baseada em precedentes por eles estabelecidos.

Principia-se por expor entendimento cristalizado na Súmula n. 343 do Supremo Tribunal Federal, do seguinte teor: "Não cabe ação rescisória por ofensa a literal disposição de lei, quando a decisão rescindenda se tiver baseado em texto legal de interpretação controvertida nos tribunais".

Em linhas gerais, o enunciado estabelece que, sendo controvertida a matéria nos tribunais, não há violação literal a preceito normativo, hábil a ensejar a ação rescisória.

O Superior Tribunal de Justiça vem entendendo ser aplicável o comando do enunciado supra transcrito, salientando não caber ação rescisória quando o julgado rescindendo se tiver baseado em uma das interpretações de lei possíveis à época de sua 
prolação, embora diversa do entendimento da jurisprudência no momento da interposição da ação em questão.

Confira-se:

"Processual Civil. Ação rescisória. Prazo decadencial. Termo inicial. Trânsito em julgado da última decisão proferida nos autos. Art. 495 do CPC. Súmula n. 401/STJ. Coisa julgada 'por capítulos'. Inadmissibilidade. SFH. Utilização do IPC (84,32\%) no mês de abril de 1990. Adoção da taxa referencial como índice de atualização monetária (Lei n. 8.177/1991). Violação de literal disposição de lei. Art. 485, V, do CPC. Súmula n. 343/STF. Violação do art. 535 do CPC não configurada.

1. ...

2. ....

3. ...

4. A ação rescisória fundada no art. $485, \mathrm{~V}$, do CPC, pressupõe violação frontal e direta de literal disposição de lei, sendo certo, ainda, que a adoção pela decisão rescindenda de uma dentre as interpretações cabíveis não enseja a rescisão do decisum. Incidência da Súmula n. 343/STF: 'Não cabe ação rescisória por ofensa a literal disposição de lei, quando a decisão rescindenda se tiver baseado em texto legal de interpretação controvertida nos tribunais'.

5. No caso concreto, diversamente da atual jurisprudência, o acórdão rescindendo (transitado em julgado em 19/12/2001), embasado em uma das intepretações possíveis à época do julgamento (15/8/2000), decidiu pela aplicação do BTNf para a correção monetária do saldo devedor dos contratos do SFH no mês de março de 1990 no percentual de 41,28\% (quarenta e um inteiros e vinte e oito centésimos percentuais), bem como pela impossibilidade de aplicação da TR nos contratos de financiamento habitacional celebrados antes da Lei n. 8.177, de $1^{\circ}$ de março de 1991, sob pena de locupletamento. 
6. A pacificação da jurisprudência desta Corte em sentido contrário e posteriormente ao acórdão rescindendo não afasta a aplicação do enunciado n. 343 da Súmula do STF.

7. Firmado o posicionamento deste Tribunal Superior quanto à interpretação de determinada norma infraconstitucional, torna-se cabível a ação rescisória contra julgado proferido em data posterior à pacificação, desde que contrário ao entendimento consolidado no STJ, afastando-se, em tal hipótese, a incidência do referido enunciado sumular.

8. Recurso especial conhecido e parcialmente provido." (REsp 736.650/MT, relator Ministro Antônio Carlos Ferreira, j. 20/08/2014, Corte Especial do Superior Tribunal de Justiça).

Como se observa, a orientação do Superior Tribunal de Justiça é no sentido de que não há violação manifesta de norma jurídica, hábil a ensejar ação rescisória, se a decisão rescindenda se fundamentou em entendimento jurisprudencial - a respeito de lei admissível à época de sua prolação, mesmo que, posteriormente, a jurisprudência tenha se fixado em sentido diverso do decidido. Outrossim, somente é admissível a ação rescisória se o julgado rescindendo é posterior ao entendimento consagrado em sentido contrário.

Ocorre, porém, que o Supremo Tribunal Federal, quando se têm em vista questões de índole constitucional, tem afastado a aplicação da Súmula n. 343, com base em argumentos centrados na força dispositiva constitucional e no princípio da máxima efetividade da norma constitucional.

Tal exegese já foi observada no julgamento do Recurso Extraordinário 89.108, ocorrido em 28/08/1980.

Colhe-se, com efeito, do voto do Ministro Soares Munhoz que "o texto legal controvertido não é de lei ordinária, mas da própria Constituição. Entendo, por isso, que não é aplicável a Súmula 343. A inconstitucionalidade é o maior vício que uma lei pode conter. O efeito da declaração de inconstitucionalidade é 'ex tunc'."

Sobre o tema, Ministro Gilmar Mendes encampou de vez a tese em questão, em seu voto como relator dos Embargos de Declaração no Recurso Extraordinário 328.8121/AM, ocorrido em 06/03/2008. 
Entendeu o eminente Ministro que a Súmula n. 343 do STF não deveria ser aplicada aos processos que identificam matéria contraditória quando da discussão originária, versando sobre questão constitucional, com superveniência de jurisprudência fixada em favor da tese do autor da ação rescisória.

Embasou-se, em breve síntese, nos seguintes fundamentos: 1)- a decisão do STF que fixa uma interpretação constitucional explicita os conteúdos possíveis da ordem normativa infraconstitucional em face do parâmetro maior, que é a Constituição; 2)- a violação à norma constitucional, para fins de ação rescisória, é algo mais grave que a violação à lei; 3)- se a rescisão de uma sentença implica em fator de instabilidade, a aplicação assimétrica de uma decisão do STF em matéria constitucional oferece instabilidade maior, pois representa uma violação a um referencial normativo que dá sustentação a todo sistema; 4)- se ao STF compete, precipuamente, a guarda da Constituição Federal, sua interpretação do texto constitucional deve ser acompanhada pelos demais Tribunais, em decorrência do efeito definitivo absoluto outorgado à sua decisão; 5)- no controle difuso de constitucionalidade, o STF somente vem a apreciar a questão anos após ter sido ela decidida pelos tribunais ordinários, sendo a ação rescisória o instrumento adequado para superação da decisão divergente; 6)- A manutenção de soluções divergentes, em instâncias inferiores, ocasiona uma fragilização da força normativa da Constituição e ofende o princípio da máxima efetividade da norma constitucional; 7)- não se pode fortalecer as decisões das instâncias ordinárias em detrimento das decisões do STF.

Também releva destacar, para embasar conclusões que serão ao final lançadas, que o STF igualmente sedimentou entendimento no sentido de que não cabe ação rescisória, quando o julgado rescindendo encampou orientação jurisprudencial majoritária à época de sua prolação, mas posteriormente alterada pela Corte.

Confira-se a seguinte decisão:

“Ação rescisória. Art. 485, V, do Código de Processo Civil. Matéria Constitucional. Rescisão de acórdão que aplicou jurisprudência do STF posteriormente modificada. Não cabimento da ação rescisória como instrumento de uniformização da jurisprudência do tribunal. Precedentes. Honorários advocatícios em ação rescisória. Fixação.

1. Ao julgar, em regime de repercussão geral, o RE 590.809/RS (Min. Marco Aurélio, DJe de 24/11/2014), o Plenário não operou, 
propriamente, uma substancial modificação de sua jurisprudência sobre a não aplicação da Súmula 343 em ação rescisória fundada em ofensa à Constituição. $\mathrm{O}$ que o Tribunal decidiu, na oportunidade, foi outra questão: ante a controvérsia, enunciada como matéria de repercussão geral, a respeito do cabimento ou não da 'rescisão de julgado fundamentado em corrente jurisprudencial majoritária existente à época da formalização do acórdão rescindendo, em razão de entendimento posteriormente firmado pelo Supremo', a Corte respondeu negativamente, na consideração de que a ação rescisória não é instrumento de uniformização da sua jurisprudência.

2. Mais especificamente, o Tribunal afirmou que superveniente modificação de sua jurisprudência (que antes reconhecia e depois veio a negar o direito a creditamento de IPI em operações com mercadorias isentas ou com alíquota zero) não autoriza, sob esse fundamento, o ajuizamento de ação rescisória para desfazer acórdão que aplicara a firme jurisprudência até então vigente no próprio STF." (AR $2370 \mathrm{AgR} / \mathrm{CE}$, relator Ministro Teori Zavasxcki, j. 22/10/2015).

Enfim, o Supremo Tribunal Federal entende existir violação manifesta de norma jurídica, para fins de ação rescisória, quando o julgado rescindendo se funda em interpretação admissível à época, mas depois refutada pela Corte. E entende inexistir tal violação quando a decisão rescindenda aplica orientação jurisprudencial majoritária quando de sua prolação, mas posteriormente alterada pela Corte.

\section{V- OS ARTIGOS 475-L, INCISO II E $\S 1^{\circ}$, E 741, PARÁGRAFO ÚNICO, DO CÓDIGO DE PROCESSO CIVIL DE 1973, E O ARTIGO 525, §§ $12^{\circ}$ e $15^{\circ}$, DO CÓDIGO DE PROCESSO CIVIL DE 2.015.}

A Lei n. 11.232, de 22/12/2005, acresceu ao Código de Processo Civil então vigente o art. 475-L e seus parágrafos.

$\mathrm{O}$ art. 475 , inciso II, e $\S 1^{\circ}$, do CPC/73, está assim redigido:

“A impugnação somente poderá versar sobre:

II - inexigibilidade do título; 
$\S 1^{\circ}$ Para efeito do disposto no inciso II do caput deste artigo, considera-se também inexigível o título judicial fundado em lei ou ato normativo declarados inconstitucionais pelo Supremo Tribunal Federal, ou fundado em aplicação ou interpretação da lei ou ato normativo tidas pelo Supremo Tribunal Federal como incompatíveis com a Constituição Federal.”

O mesmo diploma legal (Lei n. 11.232/2005) também acrescentou o parágrafo único ao art. 741 do $\mathrm{CPC} / 73$.

Confira-se a redação do dispositivo, no que interessa:

“Na execução contra a Fazenda Pública, os embargos só poderão versar sobre:

II - inexigibilidade do título;

Parágrafo único: Para efeito do disposto no inciso II do caput deste artigo, considera-se também inexigível o título judicial fundado em lei ou ato normativo declarados inconstitucionais pelo Supremo Tribunal Federal, ou fundado em aplicação ou interpretação da lei ou ato normativo tidas pelo Supremo Tribunal Federal como incompatíveis com a Constituição Federal.”

Pela similitude, tais dispositivos podem ser considerados precursores do disposto no $\S 12^{\circ}$ do art. 525 do novo Código de Processo Civil.

Vale transcrever o dispositivo:

"Art. 525: Transcorrido o prazo previsto no art. 523 sem o pagamento voluntário, inicia-se o prazo de 15 (quinze) dias para que o executado, independentemente de penhora ou nova intimação, apresente, nos próprios autos, sua impugnação.

$\S 1^{\circ} \mathrm{Na}$ impugnação, o executado poderá alegar:

III - inexequibilidade do título ou inexigibilidade da obrigação;

$\S 12^{\circ}$ : Para efeito do disposto no inciso III do $\S 1^{\circ}$ deste artigo, considera-se também inexigível a obrigação reconhecida em 
título executivo judicial fundado em lei ou ato normativo considerado inconstitucional pelo Supremo Tribunal Federal, ou fundado em aplicação ou interpretação da lei ou do ato normativo tido pelo Supremo Tribunal Federal como incompatível com a Constituição Federal, em controle de constitucionalidade concentrado ou difuso.

$\S 14^{\circ}$. A decisão do Supremo Tribunal Federal referida no $\S 12$ deve ser anterior ao trânsito em julgado da decisão exequenda.

$\S 15$. Se a decisão referida no $§ 12$ for proferida após o trânsito em julgado da decisão exequenda, caberá ação rescisória, cujo prazo será contado do trânsito em julgado da decisão proferida pelo Supremo Tribunal Federal."

Como se observa, as hipóteses de rescisão da decisão exequenda, no CPC/73 e no atual CPC, são as mesmas (título executivo fundado em lei ou ato normativo considerado inconstitucional pelo Supremo Tribunal Federal, ou fundado em aplicação ou interpretação da lei ou do ato normativo tido pelo Supremo Tribunal Federal como incompatível com a Constituição Federal).

A alteração está em que, na vigência do diploma processual anterior, a impugnação e os embargos tinham efeito rescisório, mesmo quando o trânsito em julgado da decisão do STF fosse posterior ao da decisão exequenda.

No novo regime, a impugnação somente tem eficácia rescisória caso o trânsito em julgado da decisão do STF seja anterior ao da sentença exequenda.

Se, porém, a decisão da Corte Suprema for proferida posteriormente ao trânsito em julgado da sentença que configurou o título executivo, a inexigibilidade não pode ser arguida mediante impugnação, mas deve ser objeto de ação rescisória (autônoma), na forma prevista no $§ 15$ do art. 525 do novo Código de Processo Civil.

O Ministro Teori Zavascki, em artigo sobre o parágrafo único do art. 741 do Código de Processo Civil de 1973, ponderou que ele não tem aplicação universal a todas as sentenças inconstitucionais. 
Especificou, também, que são apenas três os vícios de inconstitucionalidade que permitem a utilização dos embargos com eficácia rescisória, a saber: a)- aplicação de lei inconstitucional; 2)- aplicação da lei a situação considerada inconstitucional; e 3)aplicação da lei com um sentido (= uma interpretação) tida por inconstitucional.

E, por fim, deixou explicitado:

No primeiro caso (aplicação de lei inconstitucional) supõe-se a declaração de inconstitucionalidade com redução de texto. No segundo (aplicação da lei em situação tida por inconstitucional), supõe-se a técnica da declaração de inconstitucionalidade parcial sem redução de texto. E no terceiro (aplicação de lei com um sentido inconstitucional), supõe-se a técnica da interpretação conforme a Constituição.

A ‘redução de texto’ é o efeito natural mais comum da afirmação de inconstitucionalidade em sistemas, como o nosso, em que tal vício importa nulidade: se o preceito constitucional é nulo, impõe-se seja extirpado do ordenamento jurídico, o que leva à consequente 'redução' do direito positivo.

Há situações, todavia, em que a pura e simples redução de texto não se mostra adequada ao princípio da preservação da Constituição e da sua vinculação em dimensão normativa. A técnica da declaração de inconstitucionalidade parcial sem redução de texto é utilizada justamente em situações dessa natureza, em que a norma é válida (= constitucional) quando aplicada a certas situações, mas inválida (= inconstitucional) quando aplicada a outras. O reconhecimento dessa dupla face do enunciado normativo impõe que a declaração de sua inconstitucionalidade parcial (= aplicação a certas situações) se dê sem a eliminação (=redução) do enunciado positivo, a fim de que fique preservada a sua aplicação na parte (= às situações) tida por constitucional.

É assim também a técnica de interpretação conforme a Constituição, que consiste em 'declarar a legitimidade do ato questionado desde que interpretado em conformidade com a Constituição'. Trata-se de instituto hermenêutico, 'visando a otimização dos textos jurídicos, mediante agregação de sentido, portanto, produção de sentido', especialmente para preservar a constitucionalidade da interpretação 'quando a utilização dos vários elementos interpretativos não permite a obtenção de um sentido inequívoco dentre os vários significados da norma. Daí a sua formulação básica: no caso de normas polissêmicas ou pluri-significativas, deve dar-se preferência à interpretação que lhe dê um sentido em conformidade com a Constituição.'. Também nessa técnica ocorre, em maior ou menor medida, declaração de inconstitucionalidade: ao afirmar que a norma somente é constitucional quando interpretada em determinado sentido, o que se diz, implícita mas necessariamente, é que a norma é inconstitucional quando interpretada em sentido diverso. (RP 125/79). 
Como, consoante analisado, as hipóteses previstas no $\S 12$ do art. 525 do Código de Processo Civil são as mesmas do parágrafo único do art. 741 do Código de Processo Civil revogado, a lição do Ministro Teori Zavascki lhe são igualmente aplicáveis.

Enfim, o $§ 15$ do art. 525 do novo CPC passou a prever a possibilidade de ajuizar ação rescisória, quando a sentença rescindenda se fundar em lei ou ato normativo considerado inconstitucional pelo Supremo Tribunal Federal, ou em aplicação ou interpretação da lei ou do ato normativo tido pelo Supremo Tribunal Federal como incompatível com a Constituição Federal, quando a decisão da Corte Suprema é proferida após o trânsito em julgado daquela sentença.

\section{VI - CONTROLE DE CONSTITUCIONALIDADE: POSIÇÕES DA DOUTRINA}

ABBOUD ensina que a doutrina reconhece a vinculação dos tribunais constitucionais às suas próprias decisões, mas que tal vinculação não é inexorável, podendo ser contornada diante de mutações jurídicas ou fáticas significativas (ABBOUD, 2019, p. 632).

Também, segundo o autor, quando o STF, em controle concentrado de constitucionalidade, declara a inconstitucionalidade e a nulidade da lei, retira-a do ordenamento jurídico. Nesta hipótese, a Corte Suprema fica vinculada à sua decisão e à coisa julgada anteriormente proferida. Vale dizer: não lhe é mais possível, em ocasião posterior, resgatar algo que não está mais contido na ordenança jurídica (ABBOUD, 2019, p. 636).

Diferentemente ocorre, porém, ainda de acordo com o mesmo doutrinador, quando se trata de sentenças interpretativas, como se extrai do seguinte trecho de sua obra:

Nas sentenças interpretativas em que se aplica a arguição de nulidade sem redução de texto, o STF anula o sentido apresentado pelo texto da lei de maneira inconstitucional, aceitando, no entanto, outras possibilidades interpretativas. ....

Na sentença interpretativa em que se aplica a interpretação conforme a Constituição, o STF define qual é a única interpretação constitucional de determinada lei, excluindo as demais que seriam inconstitucionais. 
$\mathrm{Na}$ prática, pode ocorrer que a única interpretação considerada constitucional pelo Supremo passe a ser considerada inconstitucional, ou a interpretação que o STF arguiu nula porque inconstitucional passe a ser constitucional. Isso ocorre porque o Supremo, quando julga processo de controle concentrado de constitucionalidade, decide abstratamente, não há um caso jurídico enquanto suporte fático a ser decidido - normatizado, impedindo que o STF possa prever toda a constelação de casos que surgirão diante da aplicação da lei que foi objeto de sentença interpretativa.

Assim, a mudança de entendimento do STF também pode ocorrer em razão de modificações fáticas e jurídicas significativas que obriguem o Supremo a rever suas decisões ou, ainda, a necessidade de revisão pode surgir em razão de mudança na composição do próprio Tribunal. Uma nova composição pode passar a entender que a única interpretação considerada constitucional deixou de ser constitucional, ou, ainda, que outras surgiram, ou, por fim, que a interpretação que considerada nula passou a ser constitucional". (ABBOUD, 2019, p. 637).

Daí a conclusão: "as decisões interpretativas, sejam as que aplicam a interpretação conforme, sejam as que utilizam a arguição de nulidade sem redução de texto, podem ser posteriormente revistas pelo STF porque, apesar de existir coisa julgada, no processo constitucional, não incide a eficácia preclusiva da sentença” (ABBOUD, 2019, p. 640).

Prosseguindo, ainda no âmbito doutrinário, deve ser destacado entendimento no sentido de que, se modificada a jurisprudência do tribunal, os efeitos de tal modificação se projetam apenas para o futuro.

Nesse sentido:

Se modificada a jurisprudência do tribunal, seus efeitos têm de ser para o futuro, ainda que a natureza da decisão judicial seja declaratória, como ocorre nas decisões que reconhecem a inconstitucionalidade ou ilegalidade da norma.

Em termos mais precisos, o jurisdicionado não pode ser prejudicado, com decisão judicial desfavorável, porque agiu em conformidade com o entendimento jurisprudencial anterior e a jurisprudência se modificou. Os atos por ele praticados sob a égide da jurisprudência anterior são plenamente válidos e eficazes e não podem ser desfeitos pela superveniência de novo entendimento dos tribunais, alteradores do entendimento anterior prevalecente. A boa-fé objetiva garante a validade e a eficácia dos atos praticados sob fundamento na jurisprudência anterior". (NERY JUNIOR e ABBOUD, 2019, p. 944/945). 


\section{VI - CONCLUSÃO: POSIÇÃO A RESPEITO DO § 15 DO ART. 525 DO CÓDIGO DE PROCESSO CIVIL.}

Pelo exposto, conclui-se que não andou bem o legislador ao estabelecer, no sobredito dispositivo de lei processual civil, a possibilidade de ação rescisória fundada em decisão do Supremo Tribunal Federal posterior ao trânsito em julgado da decisão rescindenda.

Com efeito, não se fez a devida ponderação entre, de um lado, a segurança jurídica, ínsita ao Estado Democrático de Direito, instrumentalizada pela coisa julgada, e o escopo social do processo consistente na pacificação social por meio da eliminação de conflitos e, de outro, a busca pela atuação da vontade concreta da lei e pela justiça.

Proferida uma decisão judicial coberta pela coisa julgada, pode-se concluir que tal se deu após o devido processo legal, em que as partes tiveram todas as oportunidades para influir no desfecho do caso.

O vencedor espera colher os frutos de sua vitória e, a parte vencida, porque colaborou para o teor da decisão final, encontra-se resignada com a perda.

Não é possível, em função de um fato futuro, e de alguma maneira mesmo incerto, qual seja, uma decisão em sentido contrário do Supremo Tribunal Federal, fazer ressuscitar tema já resolvido e consolidado entre os litigantes.

Retomando o ensinamento de Portalis, citado por Vicente Ráo, tal consistiria em fazer reviver, para o tempo que já se foi, "as nossas dores, sem nos restituir nossas esperanças."

Vale concluir ainda, em paralelo, como visto, que todas as hipóteses previstas tradicionalmente na legislação processual civil brasileira, autorizadoras da ação rescisória, guardam consonância com situação pretérita.

Já na hipótese do $\S 15$ do art. 525 do Código de Processo Civil, na demanda originária, nenhuma ofensa houve ao contraditório e ao devido processo legal. Houve oportunidade para que todas as alegações possíveis tivessem sido deduzidas e para que todas as provas lícitas e idôneas tivessem sido apresentadas. 
Logo, uma decisão futura do Supremo Tribunal Federal, posterior ao trânsito em julgado da sentença rescindenda, não pode modificar o que se definiu como passado imutável.

Mormente se se considerar que as partes envolvidas sequer têm condições de prever se a questão julgada chegará a ser analisada pelo STF (no recurso extraordinário, há o filtro da repercussão geral) e, em caso positivo, em qual sentido a Corte Suprema irá decidir.

Para citar um exemplo da seara criminal, o Superior Tribunal de Justiça havia firmado entendimento no sentido de que "a aplicação da causa de diminuição de pena prevista no art. $33, \S 4^{\circ}$, da Lei n. 11.343/2006 não afasta a hediondez do crime de tráfico de drogas, uma vez que a sua incidência não decorre do reconhecimento de uma menor gravidade da conduta praticada e tampouco da existência de uma figura privilegiada do crime" (REsp 1.329.088/RS, Terceira Seção).

Certamente, tal entendimento serviu de orientação às Varas de Execuções Criminais do país, para o cálculo da fração diferenciada para progressão de regime (para crimes hediondos e equiparados, 2/5 para o sentenciado primários, e 3/5 para o reincidente, conforme $\S 2^{\circ}$ do art. $2^{\circ}$ da Lei n. 8.072/90).

Ocorreu que o Supremo Tribunal Federal, no julgamento do Habeas Corpus n. 118.553/MS, datado de 23 de junho de 2.016, relatora Ministra Cármen Lúcia, orientouse em sentido diverso, estabelecendo que "o tráfico de entorpecentes privilegiado (art. 33, $\S 4^{\circ}$, da Lei n. 11.343/2006) não se harmoniza com a hediondez do tráfico de entorpecentes definido no caput e $\S 1^{\circ}$ do art. 33 da Lei de Tóxicos".

Situações tais podem ocorrer também, evidentemente, na seara cível, em que possa ter aplicação o $§ 15$ do art. 525 do Código de Processo Civil.

Enfim, não se coaduna com a segurança jurídica a hipótese de rever uma situação consolidada, com base em futuro entendimento do STF que não se tem condições de prever.

De forma conexa, diga-se, como mencionado na lição de Kelsen acima reproduzida, que a interpretação de uma lei (e da própria Constituição) não conduz necessariamente a uma única solução como sendo a única correta, mas a várias soluções. 
Por consequência, o simples fato de uma decisão de instância inferior não trilhar o entendimento que foi posteriormente fixado pelo Supremo Tribunal Federal não significa que padeça de algum vício, ou que deva ser objeto de rescisão.

Deve ser lembrado, mais, que, segundo a lição citada de Teori Zavascki, dente as hipóteses previstas no $\S 12$ do art. 525 do Código de Processo Civil (e que, portanto, autorizam a rescisão do julgado na forma do § 15), estão as decisões do Supremo Tribunal Federal que reconhecem a inconstitucionalidade sem redução de texto e as que aplicam a técnica da interpretação conforme a Constituição.

Ocorre que, no ensinamento doutrinário de Georges Abboud, também trazido à colação no desenvolvimento deste trabalho, é justamente nas sentenças interpretativas (inconstitucionalidade sem redução de texto e interpretação conforme a Constituição) que se confere ao Supremo Tribunal Federal o poder de rever suas próprias decisões.

Suponha-se, então, que tenha sido julgada procedente a ação rescisória fundada no $\S 15$ do art. 525 do Código de Processo Civil, e, posteriormente, a Suprema Corte, valendo-se da possibilidade de rever suas sentenças interpretativas, passe a interpretar o texto constitucional na forma como foi aplicada pela decisão rescindenda.

Seria, então, o caso de se admitir nova ação rescisória da rescisória ? (em tese, possível).

É evidente que, a tal ponto de insegurança jurídica não se pode chegar, mormente se se considerar que um dos escopos do processo é a pacificação social.

Pondere-se, ainda, que, segundo orientação do Supremo Tribunal Federal acima colacionada (Ag. Reg. Na ação rescisória 2.370/CE), restou assentado não caber ação rescisória contra decisão fundada em corrente jurisprudencial majoritária, ainda que depois a jurisprudência da Suprema Corte venha a se inclinar em sentido contrário.

Da mesma maneira, de acordo com lição doutrinária também citada, se modificada a jurisprudência do tribunal, seus efeitos têm que ser para o futuro, por força do princípio da boa-fé objetiva.

O $§ 15$ do art. 525 do Código de Processo Civil também peca neste particular, na medida em que sequer ressalva as situações em que já havia entendimento jurisprudencial sedimentado no mesmo sentido da decisão rescindenda à época de sua prolação e posteriormente alterado. 
Prosseguindo, os argumentos lançados pelo eminente Ministro Gilmar Mendes para a não aplicação da Súmula n. 343 do STF quando se trata de questão constitucional, aos quais se fez alusão de forma resumida no curso do presente trabalho, não se sobrepõem, com o devido respeito, à conclusão que se vem de chegar.

Não se trata de ignorar a força normativa da Constituição, nem a relevante função do Supremo Tribunal Federal enquanto seu guardião.

Certamente, as decisões da Corte Suprema brasileira têm enorme peso e devem ser observadas pelas demais instâncias.

No entanto, tal observância deve ocorrer sem prejuízo de situações já consolidadas pela coisa julgada e da observância do escopo social do processo.

Vale dizer: nos casos em que não tenha havido trânsito em julgado e em situações futuras, as decisões do Supremo Tribunal Federal deverão ser estritamente encampadas pelos órgãos inferiores do Poder Judiciário.

Não se trata, também, de fortalecer as decisões das instâncias ordinárias em detrimento das do Supremo Tribunal Federal.

Cuida-se, isto sim, de respeito às regras do jogo, na medida em que não se tem em vista qualquer decisão de instância ordinária, mas de decisão acobertada pelo manto da coisa julgada, esta própria objeto de previsão constitucional.

Tampouco se trata de permitir decisões díspares a respeito da mesma questão constitucional.

Afinal, por um lado, como já pontuado, a ação rescisória, ao contrário do recurso extraordinário, não tem por função a uniformização de jurisprudência. E, por outro lado, por força do devido processo legal, a parte que teve contra si constituído título executivo judicial teve todas as oportunidades de defesa, inclusive no plano recursal. Se prevaleceu, na situação concreta, uma interpretação razoável da lei e da Constituição, não há razão para que entendimento posterior ao trânsito em julgado, ainda que da Corte Suprema, desconstitua a situação consolidada.

Outrossim, o fato de a questão constitucional somente chegar à Suprema Corte, no controle difuso de constitucionalidade, após razoável período de tempo, não pode também servir de fundamento para a desconstituição da coisa julgada, na medida em que 
se trata de decorrência própria da prestação jurisdicional, tal como prevista na Constituição.

A se entender de modo contrário, também os Tribunais de Justiça e o Superior Tribunal de Justiça poderiam se arvorar no mesmo argumento para rever decisões das instâncias iniciais com trânsito em julgado, na medida em que, inevitavelmente, as questões tratadas no processo somente são por eles apreciadas em um segundo ou terceiro momento.

Em suma, não é possível afastar, mesmo em sede de controle de constitucionalidade, a Súmula n. 343 do STF. Logo, a ação rescisória de que trata o $§ 15$ do art. 525 do Código de Processo Civil de 2015 não deve ter aplicação às hipóteses em que a decisão rescindenda tenha se baseado em lei ou ato normativo de interpretação controvertida na jurisprudência dos tribunais e, com maior dose de razão, às hipóteses em que a decisão rescindenda tenha se fundado em interpretação dominante na jurisprudência. Ao contrário, o dispositivo da lei processual civil somente deve ser aplicado aos casos em que a decisão a ser rescindida tenha se baseado em interpretação não condizente com o entendimento da jurisprudência dominante e que depois venha a ser reafirmada pelo Supremo Tribunal Federal, por força da interpretação sistemática com o art. 966, inciso V, do Código de Processo Civil de 2.015. Observar-se-á, na última hipótese, a inovação quanto ao prazo previsto no $§ 15$ do art. 525 .

\section{REFERÊNCIAS}

ABBOUD. Georges. Processo Constitucional Brasileiro. São Paulo: Revista dos Tribunais, 2019.

BARBOSA MOREIRA, José Carlos. Comentários ao Código de Processo Civil, volume V. Rio de Janeiro: Editora Forense, 1998.

CASTRO, Gina Gouveia Pires de; NATHALIA, Thaminne; SANTOS NETO, Antônio Beserra dos. CONTROLE DE CONSTITUCIONALIDADE NO BRASIL E ARGENTINA: AS ORIGENS E INFLUÊNCIAS DO CONTROLE DE CONSTITUCIONALIDADE SOB UMA PERSPECTIVA COMPARADA. Revista Juridica, [S.1.], v. 4, n. 49, p. 418 - 439, nov. 2017. ISSN 2316-753X. Disponível em: 
〈http://revista.unicuritiba.edu.br/index.php/RevJur/article/view/2300/1430>. Acesso em: 26 abr. 2020. doi:http://dx.doi.org/10.21902/revistajur.2316-753X.v4i49.2300.

DINAMARCO, Cândido Rangel. Instituições de Direito Processual Civil, volume III. São Paulo: Malheiros Editores, 2005.

DINAMARCO, Cândido Rangel. A instrumentalidade do Processo. São Paulo: Malheiros Editores, 1999.

GONÇALVES, Marcelo Barbi. Ação Rescisória e Uniformização Jurisprudencial: considerações sobre a jihad nomofilática. In: DIDIER JUNIOR, Freddie (Org). Processo nos Tribunais e Meios de Impugnação às Decisões Judiciais. Bahia: JusPodivm, 2016, p. 157-191).

KELSEN, Hans. Teoria Pura do Direito. São Paulo: Martins Fontes, 1987.

NERY JUNIOR, Nelson; NERY, Rosa Maria de Andrade. Código de Processo Civil Comentado. São Paulo: Revista dos Tribunais, 2019.

NERY JUNIOR, Nelson; ABBOUD, Geoges. Direito Constitucional Brasileiro. São Paulo: Revista dos Tribunais, 2019.

RÁO, Vicente. O Direito e a Vida dos Direitos, volume 1, São Paulo: Revista dos Tribunais, 1997.

PEREIRA, Rosalina Pinto Pereira. O art. 485, V, do Código de Processo Civil. Revista de Processo. V. 86, p. 112-147.

ZAVASCKI, Teori Albino. Embargos à execução com eficácia rescisória: sentido e alcance do art. 741, parágrafo único do CP. Revista de Processo v. 125, p. 79-91).

STF. Embargos no Recurso Extraordinário n. 89.108/GO - Goiás, relator Ministro Cunha Peixoto. Data do julgamento: 09 de abril de 1981. Disponível em < http://redir.stf.jus.br/paginadorpub/paginador.jsp?docTP=AC\&docID=47397>， acesso em 06 de dezembro de 2.019.

STF. Embargos de Declaração no Recurso Extraordinário n. 328.812-1/AM - Amazonas, relator Ministro Gilmar Mendes. Data de julgamento: 06 de março de 2.0108. Disponível em <http://redir.stf.jus.br/paginadorpub/paginador.jsp?doc TP=AC\&docID=524429> acesso em 06 de dezembro de 2.019 .

STF. Agravo Regimental na Ação Rescisória 2.370/CE - Ceará, relator Ministro Teori Zavascki. Data de julgamento: 22 de outubro de 2.015. Disponível em < 
http://redir.stf.jus.br/paginadorpub/paginador.jsp?docTP=TP\&docID=9772282>, acesso em 06 de dezembro de 2.019.

STF. Habeas Corpus n. 118.533/MS - Mato Grosso do Sul, relatora Ministra Carmen Lúcia. Data de julgamento: 23 de junho de 2.016. Disponível em http://redir.stf.jus.br/paginadorpub/paginador.jsp?docTP=TP\&docID=11677998, acesso em 06 de dezembro de 2.019.

STJ, Ação Rescisória n. 2625/PR - Paraná, relator Ministro Sebastião Reis Junior. Data do julgamento: 11 de setembro de 2.013. Disponível em <https://scon.stj.jus.br/SCON/jurisprudencia/toc.jsp?livre=\%28\%22TERCEIRA+SECA $\underline{\mathrm{O} \% 22 \% 29 . \mathrm{ORG} . \& \text { processo }=2625 \& \mathrm{~b}=\mathrm{ACOR} \& \text { thesaurus }=J U R I D I C O \& p=\text { true }>}>$, acesso em 06 dezembro de 2.019 .

STJ, Recurso Especial n. 736.650/MT - Mato Grosso, relator Ministro Antônio Carlos Ferreira. Data do julgamento 20 de agosto de 2.014. Disponível em < https://ww2.stj.jus.br/processo/revista/inteiroteor/?num_registro=200500478746\&dt_pu blicacao=01/09/2014> , acesso em 06 de dezembro de 2.019 .

STJ, Recurso Especial Representativo da Controvérsia n. 1.329.088/RS - Rio Grande do Sul, relator Ministro Sebastião Reis Junior. Data do julgamento: 13 de março de 2.013. Disponível

em $<$ https://ww2.stj.jus.br/processo/revista/documento/mediado/?componente=ATC\&seque ncial $=26642239 \&$ num_registro $=201201242080 \&$ data $=20130426 \&$ tipo $=51 \&$ formato $=P$ DF>, acesso em 06 de dezembro de 2.019. 